2. Hypophysectomized rats showed a decreased recovery of labelled leucine in cytoplasmic protein, each of the fractions sharing in this decrease. The recovery tended to be even lower after growthhormone treatment in the case of the cytoplasm as a whole and of the microsomal fraction.

3. Adrenalectomized rats showed a decreased recovery of leucine in the protein of the cytoplasm as a whole and of the microsomal fraction, but the decrease was smaller than that observed after hypophysectomy.

4. Hypophysectomized rats showed a decreased recovery of labelled orotic acid in the RNA of the mitochondrial fraction, the fluffy layer, and the microsomal fraction. These effects of hypophysectomy were not significantly influenced by growth hormone.

5. Adrenalectomized rats showed a decreased recovery of orotic acid in the RNA of the microsomal fraction, but an increased recovery in that of the cytoplasm as a whole, of the supernatant fraction, and of the ultracentrifugal fraction.

The experiments were performed in the Isotope Unit of the Institute at Chalfont St Giles, Bucks, by courtesy of Professor J. A. V. Butler. Valuable help in various aspects of the investigation was given by Mr R. T. Charles, Dr P. Cohn, Dr A. R. Crathorn, Mr C. Smith and Mrs J. Q. Tapley. The growth hormone was provided by Dr S. L. Steelman of Armour and Co., Chicago. The investigation was supported by grants to the Chester Beatty Research Institute (Institute of Cancer Research: Royal Cancer Hospital) from the British Empire Cancer Campaign, the Jane Coffin Childs Memorial Fund for Medical Research, the Anna Fuller Fund, and the National Cancer Institute of the National Institutes of Health, U.S. Public Health Service.

\section{REFERENCES}

Awapara, J., Marvin, H. N. \& Wells, B. B. (1949). Endocrinology, 44, 378.

Barnum, C. P., Huseby, R. A. \& Vermund, H. (1953). Cancer Res. 13, 880.

Bartlett, P. D. \& Glynn, R. (1950). J. biol. Chem. 187, 261.
Brachet, P. (1955). In The Nucleic Acids, vol. 2, p. 475. Ed. by Chargaff, E. \& Davidson, J. N. New York: Academic Press.

Clark, I. (1953). J. biol. Chem. 200, 69.

Elson, L. A. (1952). Brit. J. Cancer, 6, 392.

Fraenkel-Conrat, J. \& Li, C. H. (1949). Endocrinology, 44, 487.

Gaebler, O. M. (1955). In The Hypophyseal Growth Hormone, Nature and Actions, p. 383. Ed. by Smith, R. W., Gaebler, O. H. \& Long, C. N. H. New York: The Blakiston Division, McGraw Hill.

Geschwind, I., Li, C. H. \& Evans, H. M. (1950). Arch. Biochem. 28, 73.

Geschwind, I., Li, C. H. \& Evans, H. M. (1951). Arch. Biochem. Biophys. 31, 168.

Heidelberger, C. \& Hurlbert (1950). J. Amer. chem. Soc. 72, 4704.

Hultin, T. (1955). Exp. Cell Res. (Suppl.), 3, 210.

Hurlbert, R. B. \& Potter, V. R. (1952). J. biol. Chem. 195, 257.

Johnson, T. B. \& Cretcher, L. H. (1915). J. Amer. chem. Soc. 37, 2147.

Keller, E. B., Zamecnik, P. C. \& Loftfield, R. B. (1954). J. Histochem. Cytochem. 2, 378.

Kit, S. \& Awapara, J. (1954). Endocrinology, 55, 186.

Lee, N. D., Anderson, J. T., Miller, R. \& Williams, R. H. (1951). J. biol. Chem. 192, 733.

Lee, N. D. \& Williams, R. H. (1952). Endocrinology, 51, 451.

Lee, N. D. \& Williams, R. H. (1953). J. biol. Chem. 200, 451.

Littlefield, J. W., Keller, E. B., Gross, J. \& Zamecnik, P. C. (1955). J. biol. Chem. 217, 111.

Logan, J. E., Heagy, F. C. \& Rossiter, R. J. (1955). Canad. J. Biochem. Physiol. 33, 54.

Reid, E. (1955). Nature, Lond., 175, 461.

Reid, E. (1956). J. Endocrinol. 13, 319.

Reid, E. \& Stevens, B. M. (1956). Biochim. biophys. Acta, $18,554$.

Sakami, W., Evans, W. E. \& Gurin, S. (1947). J. Amer. chem. Soc. 69, 1111.

Schmidt, G. \& Thannhauser, S. J. (1945). J.biol. Chem.161, 83.

Simkin, J. L. (1955). Résumés des Communications, 3rd Int. Congr. Biochem., Brussels, p. 74.

Smellie, R. M. S., McIndoe, W. M., Logan, R., Davidson, J. N. \& Dawson, I. M. (1953). Biochem. J. 54, 280.

Winnick, T. (1950). Arch. Biochem. $27,63$.

\title{
The Metabolism of the Monochloronitrobenzenes in the Rabbit
}

\author{
BY H. G. BRAY, SYBIL P. JAMES AND W. V. THORPE \\ Department of Physiology, The Medical School, University of Birmingham
}

(Received 8 March 1956)

The results of a detailed study of the metabolism of tetra- and penta-chloronitrobenzenes in the rabbit (Bray, Hybs, James \& Thorpe, 1953; Betts, James \& Thorpe, 1955) were of sufficient interest to justify an investigation of the metabolic fate of the complete series of chloromononitrobenzenes. One feature of the metabolism of these polychloronitrobenzenes which particularly attracted our attention was that the mercapturic acids appeared to be formed by replacement of the nitro group by an acetylcysteyl group (acetylcysteyldenitration) and not by the usual process which is, in effect, an acetylcysteyldeprotonation and which occurs, for example, with naphthalene (Bourne \& Young, 1934; Ing, Bourne \& Young, 1934; Stekol, 1935), anthracene (Boyland \& Levi, 1936) and the mono- 
halogenobenzenes (Jaffe, 1879; Baumann \& Preusse, 1879; Baumann \& Schmitz, 1895; Young \& Zbarsky, 1944). Another feature was the failure to detect any excretion of chloroacetanilides, although comparatively large amounts of polychloroanilines were excreted. A preliminary examination of diand tri-chloronitrobenzenes (Bray, James \& Thorpe, $1955 a, b)$ has revealed a similar excretion of the corresponding unconjugated chloroanilines and, in most cases, the formation of mercapturic acids. These mercapturic acids were, however, formed, in effect, by acetylcysteyldechlorination, and not by replacement of the nitro group.

The present paper describes the effect of administration of $o-, m$ - and $p$-chloronitrobenzene on the excretion by the rabbit of glucuronic acid, ethereal sulphate, mercapturic acid and diazotizable amines. Several phenolic metabolites have been identified by paper chromatography. The monochloronitrobenzenes are too toxic to permit the administration of large doses.

\section{MATERIALS}

Melting points of all compounds are uncorrected and agree with those given in the literature unless stated otherwise. The chloronitrobenzenes and chloroanilines were purchased. Chloroacetanilides (m.p. o $87^{\circ}, m 72^{\circ}, p 178^{\circ}$ ) were prepared by acetylation of the corresponding anilines with acetic anhydride. The methods of preparation and melting points of the chloronitrophenols and aminochlorophenols which are possible metabolites of the chloronitrobenzenes are given in Table 1. All aminochlorophenols were prepared by reduction of the corresponding nitro compounds with alkaline $\mathrm{Na}_{2} \mathrm{~S}_{2} \mathrm{O}_{4}$. Only the following require comment.

3-Amino-2-chlorophenol. Schlieper (1893) gave m.p. 85-87 for an impure specimen. Our material had m.p. 110-111 ${ }^{\circ}$. (Found: N, 9.8. Calc. for $\mathrm{C}_{6} \mathrm{H}_{6} \mathrm{ONCl}: \mathrm{N}, 9 \cdot 8 \%$.)

3-Chloro-5-nitrophenol. The method of Hodgson \& Wignall (1926) was modified by using $\mathrm{H}_{2} \mathrm{~S}$ in ethanolic ammonia instead of sodium trisulphide for the reduction of 3:5-dinitroanisole. The experimental details given by Hodgson \& Wignall for the demethylation of 3-chloro-5nitroanisole are not clear. When the sulphuric acid solution is poured on to ice the desired product is left in solution and not in the precipitate, which is the unchanged anisole.

2-Amino-6-chlorophenol, m.p. $74^{\circ}$, is unstable. It gave a red-brown colour with $\mathrm{FeCl}_{3}$. The diacetyl derivative, 2-acetamido-1-acetoxy-6-chlorobenzene, m.p. $128^{\circ}$, formed long colourless needles from water. (Found: C, 53.2; H, 4.4 ; $\mathrm{N}, 6 \cdot 2 . \mathrm{C}_{10} \mathrm{H}_{10} \mathrm{O}_{3} \mathrm{NCl}$ requires $\mathrm{C}, 52 \cdot 8 ; \mathrm{H}, 4 \cdot 4 ; \mathrm{N}, 6 \cdot 2 \%$.)

3-Amino-5-chlorophenol, colourless needles, m.p. $129^{\circ}$, which rapidly turned black in air, gave a brown colour with $\mathrm{FeCl}_{3}$. 3-Acetamido-5-chlorophenol, m.p. 161 ${ }^{\circ}$, formed colourless prisms from aqueous ethanol. (Found: $\mathbf{N}, \mathbf{7 \cdot 8}$. $\mathrm{C}_{8} \mathrm{H}_{8} \mathrm{O}_{2} \mathrm{NCl}$ requires $\mathrm{N}, 7 \cdot 6 \%$.)

5-Amino-2-chlorophenol, m.p. $158^{\circ}$, colourless needles from aqueous ethanol, gave a brown colour with $\mathrm{FeCl}_{3}$. (Found: $\mathrm{C}, 50 \cdot 2 ; \mathrm{H}, 4 \cdot 0 ; \mathrm{N}, 9 \cdot 6 ; \mathrm{Cl}, 24 \cdot 3$. Calc. for $\mathrm{C}_{6} \mathrm{H}_{6} \mathrm{ONCl}$ : $\mathrm{C}, 50 \cdot 2 ; \mathrm{H}, 4 \cdot 2 ; \mathrm{N}, 9 \cdot 8 ; \mathrm{Cl}, 24 \cdot 7 \%$ ) (This compound is mentioned by Borowski (1951) but no properties or method of preparation are given.)
Mercapturic acids were prepared according to the method of Parke \& Williams (1951). $p$-Nitroaniline was diazotized by adding $5 \mathrm{~g}$. to a solution of $\mathrm{NaNO}_{2}\left(2.5 \mathrm{~g}\right.$.) in conc. $\mathrm{H}_{2} \mathrm{SO}_{4}$ $(20 \mathrm{ml}$.) at room temp. The mixture was diluted with an equal volume of water, with cooling, before addition to the cuprous mercaptide solution. N-Acetyl-S-(2-nitrophenyl)-Lcysteine had m.p. 156-158,$[\alpha]_{\mathrm{D}}^{18}+91 \pm 4^{\circ}$ in ethanol $(c$, $0.55)$; $\lambda_{\max } 245,375 \mathrm{~m} \mu$.; $\epsilon_{\max } 13450,2890$ in $0 \cdot 1 \mathrm{~N}-\mathrm{KOH}$. (Found: C, 46.3; H, 4.5; N, 9.9; S, 11.6\%; equiv. 293. $\mathrm{C}_{11} \mathrm{H}_{12} \mathrm{O}_{5} \mathrm{~N}_{2} \mathrm{~S}$ requires $\mathrm{C}, 46.5 ; \mathrm{H}, 4 \cdot 3 ; \mathrm{N}, 9.9 ; \mathrm{S}, 11.3 \%$; equiv. 284.) N-Acetyl-S-(4-nitrophenyl)-L-cysteine had m.p. 156-158,$[\alpha]_{\mathrm{D}}^{26}+3 \pm 6^{\circ}$ in ethanol $(c, 0 \cdot 33) ; \lambda_{\max .} 347 \mathrm{~m} \mu$.; $\epsilon_{\max } 10230$ in $0.1 \mathrm{~N}-\mathrm{KOH}$. (Found: C, 46.3; H, 4.1; N, 9.9; $\mathrm{S}, 11 \cdot 2 \%$; equiv. 287. $\mathrm{C}_{11} \mathrm{H}_{12} \mathrm{O}_{5} \mathrm{~N}_{2} \mathrm{~S}$ requires $\mathrm{C}, 46 \cdot 5 ; \mathrm{H}, 4 \cdot 3$; $\mathrm{N}, 9 \cdot 9 ; \mathrm{S}, 11 \cdot 3 \%$; equiv. 284 .)

\section{METHODS}

Animals, diet and dosage. Doe rabbits (2-3 kg. body wt.) were maintained on a constant diet of rabbit pellets and water (Bray, Ryman \& Thorpe, 1947). Dose levels were $0 \cdot 1 \mathrm{~g}$. $/ \mathrm{kg}$. for $o$-chloronitrobenzene and $o-, m$ - and $p$-chloroanilines and $0 \cdot 2 \mathrm{~g} . / \mathrm{kg}$. for $m$ - and $p$-chloronitrobenzenes. No toxic effects were observed at these levels, but larger doses caused severe anorexia and were sometimes fatal. For most purposes urines were collected each $24 \mathrm{hr}$. until metabolites were no longer excreted (usually $48 \mathrm{hr}$.). To minimize confusion with base-line values some urines, particularly for mercapturic acid determinations, were collected as separate consecutive samples from rabbits given water at intervals (see Bray, Thorpe \& White, 1951).

Ether glucosiduronic acid was determined by a naphthoresorcinol method and ethereal sulphate by a turbidimetric method (see Bray \& Thorpe, 1954). Mercapturic acid was determined by a modification (Betts et al. 1955) of the method of Stekol (1936); the concentration of $\mathrm{NaOH}$ used for the hydrolysis was $2 \mathrm{~N}$. Recovery of added $N$-acetyl- $S$ (2-nitrophenyl)-L-cysteine from water was $81 \pm 3 \%$ and of $N$-acetyl-S-(4-nitrophenyl)-L-cysteine $91 \pm 3 \%$ : corresponding recoveries from urine were $44 \pm 3$ and $63 \pm 3 \%$ respectively. $N$-Acetyl-S-(4-nitrophenyl)-L-cysteine was also determined in urine colorimetrically. Urine $(5 \mathrm{ml}$. diluted with $20 \mathrm{ml}$. of water was treated with $10 \%(\mathrm{w} / \mathrm{v})$ $\mathrm{ZnSO}_{4}, 7 \mathrm{H}_{2} \mathrm{O}(5 \mathrm{ml}$.) and $0.5 \mathrm{~N}-\mathrm{NaOH}(5 \mathrm{ml}$.), mixed and filtered. A $10 \mathrm{ml}$. sample of the filtrate was heated with $11 \mathrm{~N}-\mathrm{NaOH}$ (1 ml.) for $20 \mathrm{~min}$. in a boiling-water bath, with a 'cold finger' to reduce evaporation. The absorption of the cooled yellow solution was measured in a Spekker photoelectric absorptiometer with an Ilford filter, spectrum violet 601 (max. transmission $430 \mathrm{~m} \mu$.). The calibration curve for pure $N$-acetyl- $S$-(4-nitrophenyl)-L-cysteine was linear, and a drum reading of $0 \cdot 1$ corresponded to $5 \mu \mathrm{g}$. $/ \mathrm{ml}$. [This method is not applicable to $N$-acetyl-S-(2-nitrophenyl)-L-cysteine, which gives only a feeble yellow colour after heating with $\mathrm{NaOH}$.] Urines from animals dosed with $p$-chloronitrobenzene contained small amounts (equivalent to less than $1 \%$ of the dose on any day) of chloronitrophenols, which give a yellow colour with $\mathrm{NaOH}$ in the cold. Correction for this was made by measuring the absorption immediately after addition of $\mathrm{NaOH}$ and subtracting this value from that obtained after heating. The average recovery of the mercapturic acid added to urine was $85 \pm 5 \%$.

The method of Bratton \& Marshall (1939) was used for determination of amino compounds. In the absence of 


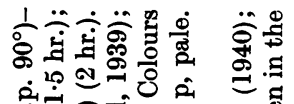
s.

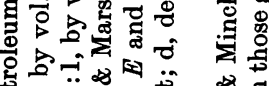

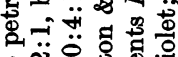
궁 密

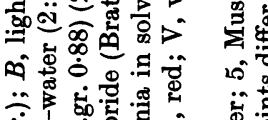

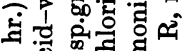

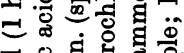

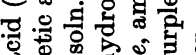

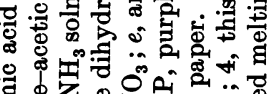
管

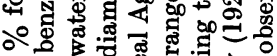

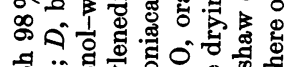

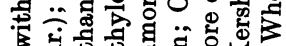

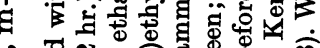
$\therefore$ 和 5 . \$

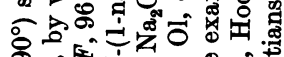
of 영 1

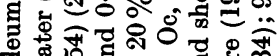

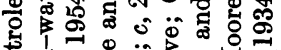
․ㅜㅇㅢ 证。

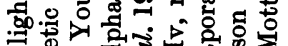
ن

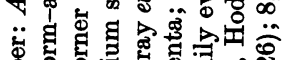

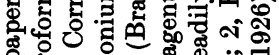
2 a

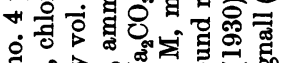
Tos워

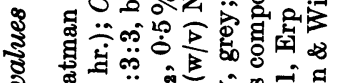
s.

a B

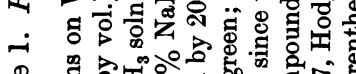

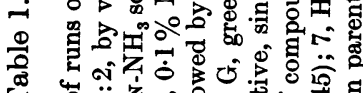

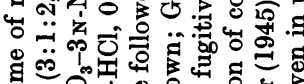

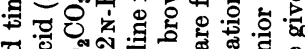

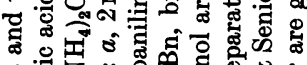
.

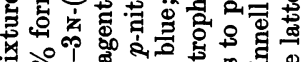

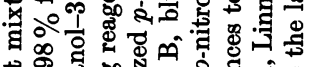

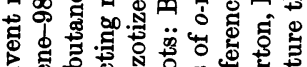

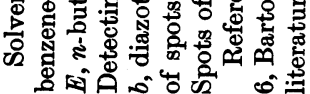
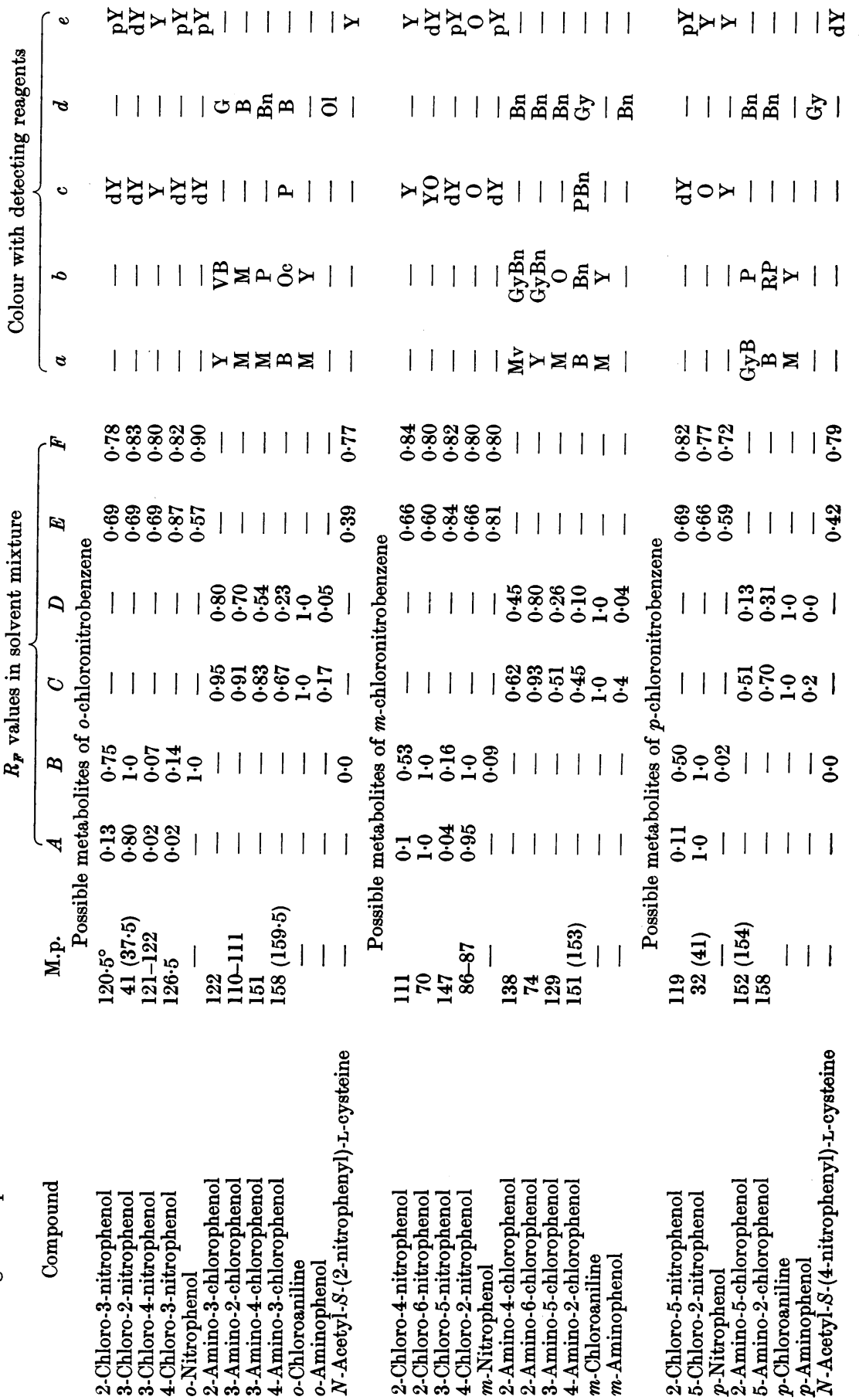

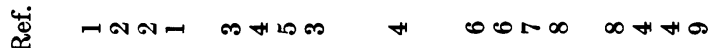


certain identification of acetylated amines, the increase obtained after hydrolysis is referred to in Table 2 as conjugated chloroaniline. Nitro compounds were reduced (Bray, Thorpe \& Wood, 1949) and determined as amino compounds.

Faeces passed during two consecutive $24 \mathrm{hr}$. periods after the administration of the compounds were ground, suspended in water and steam-distilled; nitro and amino compounds were determined in the distillates.

Paperchromatography. The procedure was as described by Bray, Thorpe \& White (1950). The solvents and detecting reagents used and the $R_{F}$ values of reference compounds are given in Table 1. For mercapturic acids, in addition to comparison of the colours and $R_{F}$ values of the spots with those of synthetic specimens, the appropriate zones were cut out and eluted with water. The presence of sulphur in the dried eluates was confirmed by fusion with sodium.

Qualitative examination of urines. The general procedure for the urines collected from rabbits dosed with chloronitrobenzenes was to prepare ether extracts A, B, C and D.

Extract $A$. Urine as collected (pH 7-8) was continuously extracted with ether for $24 \mathrm{hr}$. The extract contained chloroanilines and unconjugated aminochlorophenols and traces of chloronitrophenols.

Extract $B$. The residual urine from the preparation of extract $A$ was adjusted to $\mathrm{pH} 1$ and re-extracted with ether. This extract contained unconjugated chloronitrophenols and mercapturic acids.

Extract $C$. The urine remaining after the preparation of extract $B$ was hydrolysed by refluxing for $1 \mathrm{hr}$. with an equal volume of $10 \mathrm{~N}-\mathrm{H}_{2} \mathrm{SO}_{4}$ and then continuously extracted with ether. This extract contained chloronitrophenols present in the original urine as conjugates.

Extract $D$. The residual urine from the preparation of extract $\mathrm{C}$ was adjusted to $\mathrm{pH} 7$ and extracted with ether. This extract contained aminochlorophenols originally present as conjugates.

Extract $E$. Urines from rabbits dosed with chloroanilines were hydrolysed by refluxing with an equal volume of $10 \mathrm{~N}-\mathrm{H}_{2} \mathrm{SO}_{4}$ for $1 \mathrm{hr}$., adjusted to $\mathrm{pH} 7$ and continuously extracted with ether. The extract contained chloroanilines and aminochlorophenols originally present, free or con- jugated. This procedure was also used for isolation of 2 amino-5-chlorophenol as a metabolite of $p$-chloronitrobenzene.

\section{Isolation of metabolites}

Chloroanilines. The urine was adjusted to $\mathrm{pH} 10$ and steam-distilled. The distillates were continuously extracted with ether. The residue left after removal of solvent from the extract was treated with acetic anhydride. The melting points of the chloroacetanilides isolated were unchanged by admixture with authentic samples.

2-Amino-5-chlorophenol. An extract $\mathrm{E}$ was prepared from the urine of rabbits dosed with $p$-chloronitrobenzene and applied to a cellulose powder (Whatman standard grade) column (45 cm. long, $3 \mathrm{~cm}$. diameter). Metabolites were eluted by the organic phase of a mixture of chloroformacetic acid-water (3:1:1, by vol.) and the fractions collected were examined by paper chromatography. $p$-Chloroaniline moved with the solvent front and was separated. 2-Amino5-chlorophenol was then eluted and purified by recrystallization from aqueous ethanol $(50 \%, v / v)$. It had m.p. $150^{\circ}$, and, mixed with an authentic specimen (m.p. $152^{\circ}$ ), $151^{\circ}$. The yield was $20 \mathrm{mg}$. from an extract corresponding to a dose of $500 \mathrm{mg}$. of $p$-chloronitrobenzene.

\section{RESULTS}

The average daily excretions of normal metabolites by the rabbits used were of the same order as those found previously (e.g. Bray et al. 1953). The results obtained from the quantitative analysis of urines are summarized in Table 2. For each compound nearly the whole of the dose accounted for was excreted in urine as the chloroaniline or derivatives of phenolic metabolites. The values given for the total percentage of the dose accounted for do not include small amounts of phenolic metabolites (probably equivalent to less than $5 \%$ of the dose) which are excreted unconjugated (Table 3, extracts $A$ and B). The values for mercapturic acid from $m$-chloronitrobenzene are of doubtful significance since the increases observed after administration of

\section{Table 2. Excretion of metabolites of $\mathrm{o}-, \mathrm{m}$ - and $\mathrm{p}$-chloronitrobenzenes by the rabbit}

Results are expressed as percentages of the dose, given as means with ranges in parentheses; superior figures indicate the number of experiments. Consecutive urine samples were analysed until excretion of metabolites ceased. The unabsorbed material found in faeces was completely reduced to the chloroaniline except in the case of the para-isomer, when it consisted of approximately 1 part of $p$-chloronitrobenzene and 2 parts of $p$-chloroaniline. The values for chloroanilines were obtained from steam-distillates of the pooled urines of six rabbits.

$\begin{array}{lcc}\text { Chloronitrobenzene administered } & \text { Ortho } & \text { Meta } \\ \text { Unabsorbed } & 0 \cdot 3(0 \cdot 1,0 \cdot 5)^{2} & 0 \cdot 6(0 \cdot 5,0 \cdot 7)^{2} \\ \text { Ether glucuronide } & 42(26-56)^{3} & 33(17-58)^{9} \\ \text { Ethereal sulphate } & 24(18-31)^{3} & 18(4-30)^{6} \\ \text { Mercapturic acid } & 7(0-18)^{3} & 1(0-1)^{5} \\ \text { Chloroaniline, free } & 9 & 11 \\ \text { Chloroaniline, conjugated } & 0 & 0 \\ \text { Total accounted for } & 82 & 64\end{array}$

Para
$2 \cdot 8(2 \cdot 4,3 \cdot 2)^{2}$
$19(9-27)^{4}$
$21(15-37)^{4}$
$7(2-11)^{6 *}$
$3(0-19)^{9} \dagger$
9
4
63

* Colorimetric method. This method was more sensitive than the Stekol method and indicated that small amounts ( $1 \%$ of dose) were excreted on the fourth day after dosage.

$\uparrow$ Values by modified Stekol method. 
the dose were, in general, within the range of values obtained from normal urines. Furthermore, the presence of a mercapturic acid was not detected on paper chromatograms. The values for $o$ - and $p$ chloronitrobenzene by the Stekol method have been corrected according to the recoveries obtained when the synthetic mercapturic acids were added to urine (see Methods). That these do largely represent mercapturic acids arising from the doses given is supported by the detection of the respective mercapturic acids on paper chromatograms (see below). In the case of the para-isomer, the colorimetric method provides additional support. The values by this method are probably more reliable than those from the Stekol method since the colour obtained with normal urine is negligible. Unchanged chloronitrobenzenes were apparently absent from the urines, since the amounts of chloroanilines found were not increased after reduction with zinc and hydrochloric acid.

The metabolites identified by paper chromatography are listed in Table 3. The presence of 3chloro-4-nitrophenol in B extracts of urines from rabbits dosed with $o$-chloronitrobenzene was confirmed by identification of 4-amino-3-chlorophenol in a similar extract which had been treated with alkaline sodium dithionite. There was no evidence for loss of chlorine from any of the chloronitrobenzenes since the corresponding aminophenols were not detected in extracts $A$ and $D$ or, after reduction, in extracts $\mathrm{B}$ and $\mathrm{C}$. No metabolites giving a green (catechol) colour with ferric chloride were detected. No spots corresponding to acetamidophenols were detected on the paper chromatograms.

Attempted isolation of mercapturic acids. Purified ether extracts B were chromatographed on hydrocellulose columns eluted with solvent $E$. Although fractions containing mercapturic acids (identified by paper chromatography) were obtained from urines of rabbits dosed with $o$ - and $p$-chloronitrobenzene, no pure mercapturic acids were isolated.

\section{DISCUSSION}

The main metabolic processes undergone by the chloronitrobenzenes in the rabbit are reduction and hydroxylation. The phenols formed are excreted mainly as conjugates with sulphuric and glucuronic acids, and there is little or no acetylation of the chloroanilines formed. The hydroxylation products formed from chloronitrobenzenes and chloroanilines (Fig. 1) suggest that hydroxylation could precede or follow reduction of the nitro compound in most cases. Chloronitrophenols and aminochlorophenols were identified as metabolites of all the chloronitrobenzenes. Not all these aminochlorophenols, however, were found as metabolites of the corresponding chloroanilines, although all the aminophenols formed as metabolites of the chloroanilines were found to be metabolites of the chloronitrobenzenes. It seems likely that the

\section{Table 3. Metabolites of chloronitrobenzenes and chloroanilines detected by paper chromatography of urine extracts}

Compounds in parentheses were present in traces. For preparation of extracts see Methods section. Compounds in extracts $\mathrm{C}$ and $\mathrm{D}$ are probably excreted as conjugates.

Identified

in extract

A

B

C

$\mathrm{D}$
Ortho

After dosage with chloronitrobenzenes

o-Chloroaniline

3-Amino-4-chlorophenol

4-Amino-3-chlorophenol

(2-Chloro-3-nitrophenol)

(4-Chloro-3-nitrophenol)

(3-Amino-2-chlorophenol)

3-Chloro-4-nitrophenol

(3-Chloro-2-nitrophenol)

$N$-Acetyl-S-(2-nitrophenyl)L-cysteine

3-Chloro-4-nitrophenol

(2-Chloro-3-nitrophenol)

3-Amino-4-chlorophenol

4-Amino-3-chlorophenol

(2-Amino-3-chlorophenol)

(3-Amino-2-chlorophenol)

After dosage with chloroanilines

o-Chloroaniline

4-Amino-3-chlorophenol

(2-Amino-3-chlorophenol)
$m$-Chloroaniline

2-Amino-4-chlorophenol

4-Amino-2-chlorophenol

2-Chloro-4-nitrophenol

2-Chloro-4-nitrophenol

2-Amino-4-chlorophenol

4-Amino-2-chlorophenol

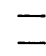

Para

$p$-Chloroaniline

2-Amino-5-chlorophenol

(2-Chloro-5-nitrophenol)

$N$-Acetyl-S-(4-nitrophenyl)L-cysteine

(2-Chloro-5-nitrophenol)

2-Amino-5-chlorophenol

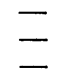

p-Chloroaniline

2-Amino-5-chlorophenol 
2-amino-4-chlorophenol from $m$-chloronitrobenzene and the 2-amino-5-chlorophenol from $p$-chloronitrobenzene are formed by hydroxylation of the chloroanilines, since the corresponding chloronitrophenols were not detected. On the other hand, the 3-amino-2-chloro- and 3-amino-4-chloro-phenol formed from $o$-chloronitrobenzene appear to have been formed by reduction of the corresponding chloronitrophenols, since the aminochlorophenols were not detected after administration of $o$-chloroaniline. Reduction of monochloronitrobenzenes in the rabbit seems to take place less readily than with some polychloronitrobenzenes, after administration of which no nitro compounds could be detected in urine (Bray et al. 1953; Betts et al. 1955). How much reduction occurs in the gut before absorption is not known.

With regard to the position of hydroxylation, the metabolites of the chloroanilines are all hydroxylated, as would be expected, either ortho or para to the amino group, and it is not surprising that 3-amino-2-chloro- and 3-amino-4-chloro-phenol, products of meta hydroxylation, were not found as metabolites of $o$-chloroaniline. Four nitrophenols were detected as metabolites of $o$-chloronitrobenzene. Two of these appear to have been formed contrary to the usual ortho- or para-direction of a chloro group and meta-direction of a nitro group. Robinson, Smith \& Williams (1951), however, showed that in the rabbit nitrobenzene can be oxidized to $o-, m$ - and $p$-nitrophenols. It may be relevant that the chloro group is anomalous in that, while being orthopara-directing, it is deactivating (see Hammett, 1937). It might therefore be expected that the directing influence of a chloro and a nitro group together in the same nucleus might be complex.

Mercapturic acid formation by acetylcysteyldechlorination appears to provide a minor metabolic pathway for $o$ - and $p$-monochloronitrobenzenes. This pathway does not seem to be available for $m$ chloronitrobenzene. Mercapturic acid formation in the chloromononitrobenzene series thus differs qualitatively as well as quantitatively from that in the chlorobenzene series. In the former, mercapturic acids are formed, in effect, either by acetylcysteyldenitration (Bray et al. 1953; Betts et al. 1955) or by acetylcysteyldechlorination (Bray et al. 1955 $a, b$; present paper), whereas mercapturic acids from the chlorobenzene series are, in effect, products of acetylcysteyldeprotonation (Jaffe, 1879; Azouz, Parke \& Williams, 1955; Parke \& Williams, 1955; Jondorf, Parke \& Williams, 1955).

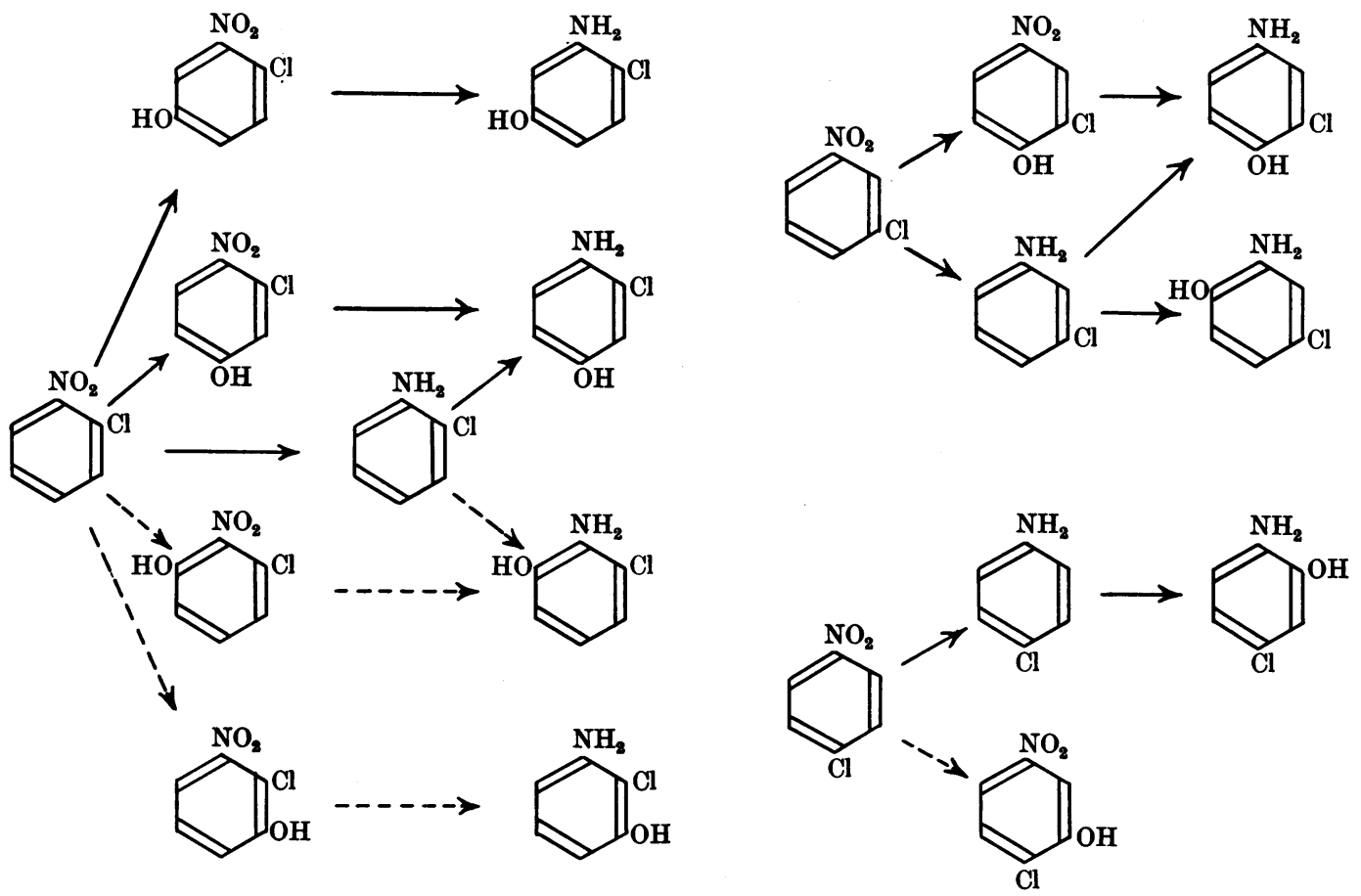

Fig. 1. Phenolic metabolites excreted (free or conjugated) in urine by the rabbit after dosage with $o-, m$ - and $p$ chloronitrobenzene and $o-, m$ - and $p$-chloroaniline. Broken arrows point to metabolites excreted only in very small amounts. (Although only a small amount of 4-chloro-3-nitrophenol was excreted, it is likely that a much greater amount was formed and reduced to 3-amino-4-chlorophenol before it was excreted.) 
The extent of mercapturic acid formation in the chlorobenzene series appears to be greatest with monochlorobenzene, and only little, if any, is formed by the polychlorobenzenes (Jondorf et al. 1955). In contrast, very little mercapturic acid is formed by the monochloronitrobenzenes but considerable amounts are formed by many polychloronitrobenzenes.

\section{SUMMARY}

1. The metabolism of $o-, m$ - and $p$-chloronitrobenzene has been studied in the rabbit within the limits imposed by the toxicity of these compounds.

2. The main products excreted in urine are phenols conjugated with glucuronic and sulphuric acids. Several amino- and nitro-chlorophenols have been identified by paper chromatography. 2Amino-5-chlorophenol has been isolated from urine of rabbits dosed with $p$-chloronitrobenzene.

3. From all three isomers about $10 \%$ of the dose was excreted as free chloroaniline.

4. Small amounts of nitrophenylmercapturic acid are formed from $o$ - and $p$-chloronitrobenzene.

We wish to thank Mrs B. G. Taylor for assistance with the quantitative analyses. Some preliminary experiments were performed by Dr Z. Hybs. We are indebted to the Microanalytical Laboratory of the Chemistry Department of the University of Birmingham for elementary microanalyses.

\section{REFERENCES}

Azouz, W. M., Parke, D. V. \& Williams, R. T. (1955). Biochem. J. 59, 410.

Barton, D. H. R., Linnell, W. H. \& Senior, N. (1945). Quart. J. Pharm. 18, 41.

Baumann, E. \& Preusse, C. (1879). Ber. dtsch. chem. Ges. 12, 806.

Baumann, E. \& Schmitz, P. (1895). Hoppe-Seyl. Z. 20, 586.

Betts, J.J., James, S. P. \& Thorpe, W. V.(1955). Biochem.J. 61, 611 .

Borowski, E. (1951). Przem. chem. 30, 647. Cited in Chem. Abstr. (1952), 46, 11141.
Bourne, M. C. \& Young, L. (1934). Biochem. J. 28, 803.

Boyland, E. \& Levi, A. A. (1936). Biochem. J. 30, 1225.

Bratton, A. C. \& Marshall, E. K. jun. (1939). J. biol. Chem. 128, 537.

Bray, H. G., Hybs, Z., James, S. P. \& Thorpe, W. V. (1953). Biochem. J. 53, 266.

Bray, H. G., James, S. P. \& Thorpe, W. V. (1955a). Biochem. J. 60, xxiii.

Bray, H. G., James, S. P. \& Thorpe, W. V. (1955b). Biochem. J. 61, v.

Bray, H. G., Ryman, B. E. \& Thorpe, W. V. (1947). Biochem. J. 41, 212.

Bray, H. G. \& Thorpe, W. V. (1954). Meth.biochem. Anal.1, 27.

Bray, H. G., Thorpe, W. V.\& White, K. (1950). Biochem. J. 46, 271.

Bray, H. G., Thorpe, W. V.\& White, K. (1951). Biochem. J. 48, 88.

Bray, H. G., Thorpe, W. V. \& Wood, P. B. (1949). Biochem. J. 44, 39.

Christiansen, W. (1923). J. Amer. chem. Soc. 45, 2192.

Corner, E. D. S. \& Young, L. (1954). Biochem. J. 58, 647.

Erp, H. van (1930). J. prakt. Chem. 127, 28.

Hammett, L. P. (1937). J. Amer. chem. Soc. 59, 96.

Hodgson, H. H. \& Kershaw, A. (1928). J. chem. Soc. p. 2703.

Hodgson, H. H. \& Moore, F. H. (1925). J. chem. Soc. 127, 1600.

Hodgson, H. H. \& Wignall, J. S. (1926). J. chem. Soc. p. 2077.

Ing, H. R., Bourne, M. C. \& Young, L. (1934). Biochem. J. 28, 809 .

Jaffe, M. (1879). Ber. dtsch. chem. Ges. 12, 1092.

Jondorf. W. R., Parke, D. V. \& Williams, R. T. (1955). Biochem. J. 61, 512.

Mottier, M. (1934). Arch. Sci. phys. nat. (v), 16, 301. Cited in Chem. Abstr. (1935). 29, 3322.

Musajo, L. \& Minchilli, M. (1940). Gazz. chim. ital. 70, 301.

Parke, D. V. \& Williams, R. T. (1951). Biochem. J. 48, 624.

Parke, D. V. \& Williams, R. T. (1955). Biochem. J. 59, 415.

Robinson, D., Smith, J. N. \& Williams, R. T. (1951). Biochem. J. 50, 228.

Schlieper, F. W. (1893). Ber. dtsch. chem. Ges. 26, 2466.

Stekol, J. A. (1935). J. biol. Chem. 110, 463.

Stekol, J. A. (1936). J. biol. Chem. 113, 279.

Young, L. \& Zbarsky, S. H. (1944). J. biol. Chem. 154, 389.

\title{
Some Chemical and Physiological Properties of 3-Indolylpyruvic Acid
}

\author{
By J. A. BENTLEY, K. R. FARRAR, S. HOUSLEY, G. F. SMITH AND W. C. TAYLOR \\ Departments of Chemistry and Botany, Manchester University
}

\section{(Received 19 October 1955)}

Stowe \& Thimann (1953, 1954) claim to have demonstrated the presence of 3-indolylpyruvic acid (IPyA) in maize endosperm and consider (1953) that it may be identical with the accelerator- $\alpha$ of Bennet-Clark \& Kefford (1953) and with other growth promoters described by Lexander (1953) and Terpstra (1953). Our work on the preparation, chemical and biological properties and chromatographic behaviour on paper of IPyA indicates that the presence of IPyA cannot be demonstrated by the methods used by Stowe \& Thimann, and that it differs from accelerator- $\alpha$ in its effect on root growth. 